\section{Carbon Dioxide Catalysis of the Formation of Pyroglutamic Acid}

Glutamic ACID and its esters and salts have a tendency to form $\alpha$-pyrrolidone derivatives ${ }^{1}$ by lactam formation:

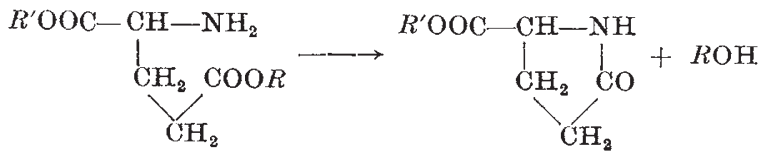

$\left(R, R^{\prime}=\mathrm{H}, \mathrm{Ca}, \mathrm{Alkyl}\right)$

The cyclization can be brought about by heating. A strong catalytic effect of ammonia has been recorded ${ }^{2}$.

Our experiments have revealed that carbon dioxide has a marked catalytic effect on the cyclization reaction. Dimethylglutamate is stable in dioxane at $25^{\circ} \mathrm{C}$. in the absence of carbon dioxide for periods of several weeks. On saturation with carbon dioxide, however, fast cyclization occurs with a half-life of approximately $10 \mathrm{hr}$. The course of the reaction can be followed by potentiometric titration of the free amino-groups.

The reaction is of second order with respect to the amino-groups belonging to the uncyclized substance. If, however, an amine is added, which is more basic than the glutamic ester itself (for example, hexylamine), the reaction becomes of first order with respect to glutamic amine. The presence of weaker amines (for example, aniline) or tertiary amines does not change either the rate or the order of the reaction.

The order of reaction does not depend on carbon dioxide pressure, all second-order plots falling on straight lines. The dependence of the overall rate on the pressure of carbon dioxide is shown in Fig. 1. The values of $k$ and $n$ can be determined from the slope and intercept in the $\log$-log plot. For dimethyl-

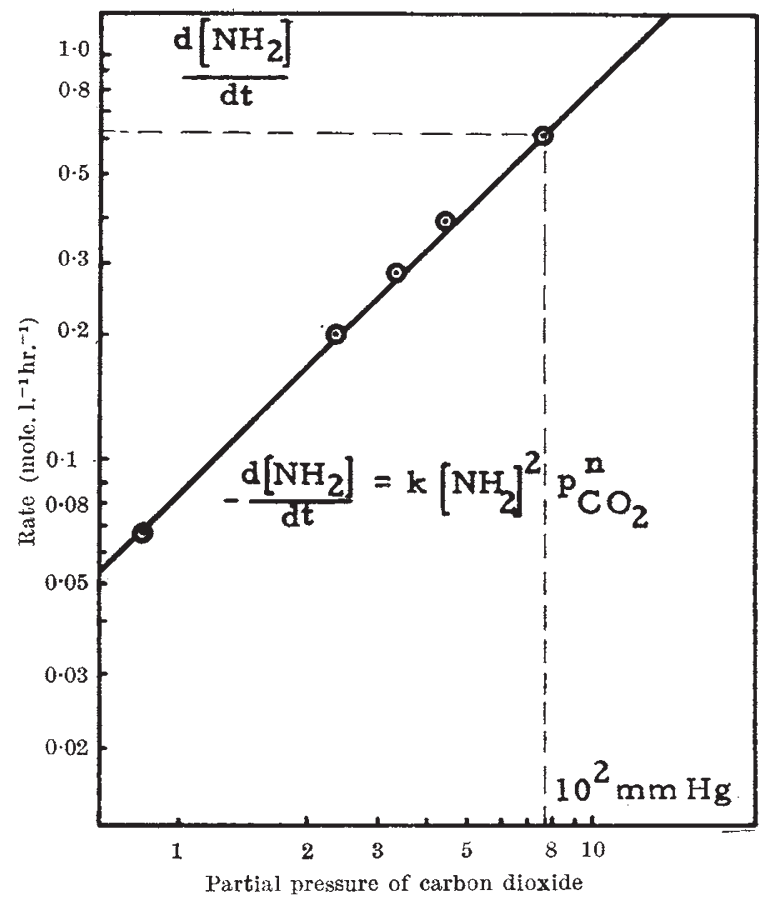

Fig. 1. The order with respect to carbon dioxide and the rate constant (k) can be determined from the plot of $\log (\mathrm{rate})$ vs. $\log \left(p_{\mathrm{CO}_{z}}\right)$. For dimethylglutamate in dioxane at $25^{\circ} \mathrm{C}, k=0.63$ 1. $\mathrm{mole}^{-1} \mathrm{~atm}^{-1} \mathrm{hr} .^{-1} ; n=1.01 \pm 0.03$ glutamate at $25^{\circ} \mathrm{C}$. in dioxane $n=1.01 \pm 0.03$ and $k=0.631$. mole $^{-1}$ atm. $.^{-1} \mathrm{hr} .^{-1}$.

On the basis of this evidence it can be concluded that carbon dioxide catalysed cyclization of the $\gamma$-esters of glutamic acid involves the formation of carbamates :

$$
2 R-\mathrm{NH}_{2}+\mathrm{CO}_{2} \longrightarrow R-\mathrm{NH}-\mathrm{COONH}_{3}-R
$$

and that it is the carbamate salt which is the reactive species. (For a similar mechanism in condensations of $\alpha$-amino-acids see ref. 3.) A weak base (aniline) will not be able to fix carbon dioxide.

In the series of glutamic diesters a marked influence of the nature of the $\gamma$-ester group is observed. The cyclization products of the diesters were all identified as the corresponding esters of pyroglutamic acid. The rate constants at $25^{\circ} \mathrm{C}$. and $720 \mathrm{~mm}$. mercury partial pressure of carbon dioxide are :

$$
\begin{array}{lc}
\text { Dimethylglutamate } & k=0.600 \text { mole. } 1 .{ }^{-1} \mathrm{hr} \cdot{ }^{-1} \\
\text { Diethylglutamate } & 0.280 \\
\text { Di- } n \text {-propylglutamate } & 0.262 \\
\text { Di-isopropylglutamate } & 0.038
\end{array}
$$

These findings have an important bearing on the polymerization of the Leuchs anhydride of $\gamma$-esters of glutamic acid. Oligopeptides of $\gamma$-benzylglutamate in dioxane lose their amino end-groups rapidly in presence of carbon dioxide, and there is some evidence that the rate of cyclization increases with the molecular weight of the peptide. It is important to notice that during the polymerization of Leuchs anhydrides the solution is saturated with carbon dioxide, and therefore the occurrence of a termination is probable, mainly in the initial part of polymerization, when the rate of growth of the chains is low and the concentration of amino-groups is high ${ }^{4}$. The cyclization reaction, therefore, has an effect on the molecular-weight distribution of the resulting polymer, tending to increase the polydispersity.

Support for this work was provided by the Union Carbide Corporation.
A. Hubert
R. BUIJLE
B. Hargitay

European Research Associates,

95 rue Gatti de Gamond,

Brussels.

May 29.

${ }^{1}$ Foreman, F. W., Biochem. J., 8, 484 (1914). Abderhalden, E., and Kautzsch, K., Z, physiol. Chem., 64, 452 (1910). Fischer, $\mathbf{E}$. , and Boehner, R., Chem. Ber., 44, 1332 (1911). Abderhalden, .., and Well, A., Z. physiol. Chem., 14, 450 (1911).

${ }^{2}$ Coleman, D., J. Chem. Soc., 2294 (1951)

${ }^{3}$ Frankel, M., and Katchalski, E., $J$ Amer. Chem. Soc., 65, 1670 (1943). Bailey, J. L., Nature, 164, 889 (1949). Khurgin, Y. J., Poroshin, K. T., and Kozarenko, T. D., Izvestia Acad. Nau $\ddot{k}$ S.S.S.R., (Chem.), 174 (1957).

'Doty, P., and Lundberg, R. D., J. Amer. Chem. Soc., 78, 4810 (1956).

\section{Isolation of the $\alpha_{2}$-Globulin Pattern on Starch Gel}

ZONE electrophoresis of serum proteins in starch gels was first described by Smithies ${ }^{1}$, who employed a borate buffer system and silver electrodes. Poulik ${ }^{2}$ described a discontinuous system using tris (trihydroxymethylamino-methane) and borate buffers for the separation of proteins. Two-dimensional electrophoresis on paper, and then on starch gel as used by Smithies and Poulik ${ }^{3,4}$, revealed at least six molecular size-groups in the $\alpha_{2}$-globulin group. A modification of this method is described, which utilizes the combination of haptoglobins with hæmoglobin to give a faintly coloured band as visual 